\title{
Stability of Titanium Dioxide Nanoparticle Agglomerates in Transitional Waters and Their Effects Towards Plankton from Lagoon of Venice (Italy)
}

\author{
Clémentine Perstrimaux • Séverine Le Faucheur • Monika Mortimer • \\ Serge Stoll • Fabrizio Bernardi Aubry • Margherita Botter • \\ Roberto Zonta • Vera I. Slaveykova
}

Received: 25 June 2014/ Accepted: 21 October 2014/Published online: 8 November 2014

(C) Springer Science+Business Media Dordrecht 2014

\begin{abstract}
The present study explores the effect of salinity and dissolved organic carbon (DOC) gradients on the stability and reactivity of titanium dioxide nanoparticle $\left(\mathrm{TiO}_{2}-\mathrm{NP}\right)$ agglomerates in ambient water from the Lagoon of Venice and their possible effect on nauplii sampled at the same locations. In all ambient water samples, $\mathrm{TiO}_{2}-\mathrm{NPs}$ formed rapidly micrometre-sized agglomerates. The increase in the salinity and concomitant decrease in DOC content induced the formation of larger agglomerates, with z-average hydrodynamic diameter increasing with $\mathrm{TiO}_{2}-\mathrm{NP}$ concentration and exposure duration. Under the studied conditions, $\zeta$-potential exhibited negative values. In line with agglomeration results, enhancement of the salinity and lower DOC resulted in less negative $\zeta$ potential with close to 0 values in the dispersions of $100 \mathrm{mg} \mathrm{L}^{-1} \mathrm{TiO}_{2}$-NPs in sea water. Two-hour exposure to micrometre-sized agglomerates of $\mathrm{TiO}_{2}-\mathrm{NPs}$ resulted in an increase in the fluorescence of propidium iodide (PI) stained nauplii in comparison with unexposed controls, but had no effect at 24-h exposure. The increase in nauplii-associated PI fluorescence was more noticeable in dispersions containing $100 \mathrm{mg} \mathrm{L}^{-1}$ than those containing $10 \mathrm{mg} \mathrm{L}^{-1} \mathrm{TiO}_{2}$-NPs, suggesting membrane permeability alteration in a concentrationdependent manner. However, the PI staining results have to be interpreted with caution because of the possible dye binding to the nauplii surface without penetration of cellular membrane. The effect of $\mathrm{TiO}_{2}-\mathrm{NPs}$ on nauplii was more pronounced at higher salinity and decreased with increasing DOC concentrations at $2 \mathrm{~h}$, while no trends were found at 24-h exposure, as well as exposure to $100 \mathrm{mg} \mathrm{L}^{-1} \mathrm{TiO}_{2}$-NPs.
\end{abstract}

C. Perstrimaux $\cdot$ S. Le Faucheur $\cdot$ M. Mortimer $\cdot$ V. I. Slaveykova $(\varangle)$

Environmental Biogeochemistry and Ecotoxicology, Faculty of Sciences, Institute F.-A. Forel, Earth and Environmental Sciences, University of Geneva, 10, route de Suisse, 1290 Versoix, Switzerland e-mail: vera.slaveykova@unige.ch

S. Stoll

Environmental Physical Chemistry, Faculty of Sciences, Institute F.-A. Forel, Earth and Environmental Sciences, University of Geneva, 10, route de Suisse, 1290 Versoix, Switzerland

F. B. Aubry · M. Botter - R. Zonta

Istituto di Scienze Marine, ISMAR, Consiglio Nazionale delle Ricerche, Arsenale-Tesa 104, Castello 2737/F, 30122 Venice, Italy 
Keywords Titanium dioxide nanoparticles - Agglomeration - Salinity gradients · Nauplii · Dissolved organic carbon · Lagoon of Venice

\section{Introduction}

Assessment of the environmental effects of nanotechnology requires understanding of their aquatic geochemistry, bioavailability and ecotoxicity in highly dynamic natural environment (Klaine et al. 2008; Lowry et al. 2012; von Moos et al. 2014). Among the metal oxide nanomaterials (NMs), titanium dioxide is the most extensively studied materials (Kahru and Ivask 2013), which is in line with their steadily progressing use in different everyday, environmental and energy applications (Chen and Mao 2007). To date, most of the available information on the geochemistry and ecotoxicity of $\mathrm{NMs}\left(\right.$ such as $\mathrm{TiO}_{2}$ ) originates from studies with model systems composed of standard organisms in artificial media (Auffan et al. 2009; Handy et al. 2008; Ju-Nam and Lead 2008; von der Kammer et al. 2010; von Moos et al. 2014). Based on the multitrophic standardized test battery, $\mathrm{TiO}_{2}$ nanoparticles $\left(\mathrm{TiO}_{2}\right.$-NPs) are classified as toxic with green algae being the most sensitive organism with $72 \mathrm{~h}$ EC50 of $9.73 \mathrm{mg} \mathrm{L}^{-1}$ (Kahru and Ivask 2013). Nonetheless, quantitative relationship between the particle physicochemical characteristics, environmental factors and induced effects is not well understood (Auffan et al. 2009; Handy et al. 2008; Ju-Nam and Lead 2008; von der Kammer et al. 2010; von Moos et al. 2014). In addition, the conceptual framework linking the exposure and effect assessment is still lacking (von Moos et al. 2014). Despite of the high importance of the model studies in exploring the underlying mechanisms of the geochemistry and ecotoxicity of NMs, their relevance with respect to natural environment has been questioned (Park et al. 2014).

Concerning NM behaviour and effects towards organisms in natural water, the available literature is scarce and non-conclusive, with virtually lacking studies on NM behaviour and effects in transitional environment, which experience temporal and local changes in salinity and organic matter concentrations, such as those encountered in a lagoon. Indeed, in addition to the intrinsic material properties and concentration, $\mathrm{TiO}_{2}-\mathrm{NP}$ stability and reactivity are governed by water characteristics such as $\mathrm{pH}$, water chemistry and dissolved organic matter (DOM) (Chowdhury et al. 2013; Ottofuelling et al. 2011; Petosa et al. 2010; Sharma 2009; von der Kammer et al. 2010); however, very few studies have examined NM behaviour in ambient water. The stability of $\mathrm{TiO}_{2}-\mathrm{NP}$ dispersion in sea water, lagoon, river and groundwater was shown to be influenced by the presence of DOM and ionic strength, but independent of $\mathrm{pH}$ (Keller et al. 2010). $\mathrm{TiO}_{2}$ aggregation dependence on the ionic strength of the solution, the (co-)presence of monovalent and divalent ions, DOM and their specific interactions were shown in synthetic and natural water samples (Ottofuelling et al. 2011). Recent study of the fate of $\mathrm{TiO}_{2}$-NPs demonstrated that salinity was the most dominant factor affecting the stability of NPs, followed by DOM (Wang et al. 2014). However, in another study, $\mathrm{TiO}_{2}$-NPs underwent fast agglomeration in synthetic and real aqueous dispersions depending mainly on the initial $\mathrm{TiO}_{2}$ concentration and to lower degree on the salt content, ionic strength and DOM (Brunelli et al. 2013). The assessment of the physicochemical behaviour of two types of $\mathrm{TiO}_{2}-\mathrm{NPs}$ differing in their mineralogy, surface area and crystallinity as function of $\mathrm{pH}$ and water composition using multidimensional parameter testing revealed the comparable behaviour in terms of dispersion stability, $\zeta$-potential and particle size (von der Kammer et al. 2010). 
The effects of NMs are mostly studied in freshwaters with relatively few studies focusing on their impact in marine and estuarine water (Baker et al. 2014; Klaine et al. 2008; Matranga and Corsi 2012). Relatively high concentrations of $\mathrm{TiO}_{2}-\mathrm{NP}$ have to interact with marine organisms in order to observe a physiological effect. For instance, dispersions of $10 \mathrm{mg} \mathrm{L}^{-1} \mathrm{TiO}_{2}-\mathrm{NP}$ agglomerates in marine water were benign to nauplii and adults of the crustacean Artemia salina exposed for $2 \mathrm{~h}$ (Ates et al. 2013), embryos of the white sea urchin Lytechinum pictus (Fairbairn et al. 2011) and the diatom Thalassiosira pseudonana for 96-h exposure (Miller et al. 2010). 10 and $100 \mathrm{mg} \mathrm{L}^{-1}$ of $\mathrm{TiO}_{2}-\mathrm{NPs}_{\mathrm{did}}$ not induce lipid peroxidation or toxicity neither in nauplii nor adults of A. salina upon 24-h exposure in sea water; however, approximately, $18 \%$ mortality was observed in nauplii after 96-h exposure to $100 \mathrm{mg} \mathrm{L}^{-1}$ of $\mathrm{TiO}_{2}$-NPs (Ates et al. 2013). $\mathrm{TiO}_{2}$-NPs in the range of $0.1-10 \mathrm{mg} \mathrm{L}^{-1}$ were reported to cause oxidative stress in marine abalone Haliotis diversicolor supertexta, but no acute effects were detected (Zhu et al. 2011). In the digestive gland of bivalve Mytilus galloprovincialis as low as $1 \mu \mathrm{g} \mathrm{L}^{-1}$, $\mathrm{TiO}_{2}-\mathrm{NPs}$ with primary size of 15-60 nm were shown to induce oxidative stress after 96-h exposure (Barmo et al. 2013). Growth rate and nitrogen fixation activity of cyanobacteria Anabena variabilis (Cherchi and $\mathrm{Gu} 2010$ ) were inhibited by $\mathrm{TiO}_{2}-\mathrm{NPs}$, with exposure duration being more important than the concentration. Finally, $10 \mathrm{mg} \mathrm{L}{ }^{-1} \mathrm{TiO}_{2}-\mathrm{NP}$ agglomerates were about six times more accumulated in the digestive gland of marine bivalve, but less toxic than bulk material (D'Agata et al. 2014).

Recently, the potential impact of NMs on the marine organisms was comprehensively reviewed (Baker et al. 2014; Matranga and Corsi 2012). It was pointed out that the release of the NMs could become important issue in the future, in particular, with regard to the sediment-dwelling organisms and filter-feeders, although the current release and concentrations in marine water are not of concern (Baker et al. 2014). Moreover, the plankton species are considered to be more "protected" in the marine systems than in freshwaters assuming that high salinity and ionic strength enhance the tendency of NMs to form agglomerates and precipitate (Baker et al. 2014; Handy et al. 2008; Klaine et al. 2008; Wang et al. 2014). However, contrary to these expectations, it has been demonstrated that in case of medaka eggs exposed to $30 \mathrm{mg} \mathrm{L}^{-1}$ model polystyrene NPs for $24 \mathrm{~h}$, the lethal effects increased proportionally to the salinity (Kashiwada 2006). Overall, the available data are controversial, and the linkage between behaviour and biological effects with environmental gradients such as salinity and dissolved organic carbon is not well understood.

The major goal of the present work, therefore, was to study the behaviour of $\mathrm{TiO}_{2}-\mathrm{NPs}$ in a dynamic transitional environment such as the Venetian Lagoon and their potential effects on natural plankton. Specific objectives were: (1) to explore the stability of the $\mathrm{TiO}_{2}$-NP dispersions along the salinity and organic matter concentration gradients in terms of size and surface charge; (2) to evaluate the effects of $\mathrm{TiO}_{2}-\mathrm{NPs}$ towards plankton nauplii commonly found in different sampling locations; and (3) to examine the linkage between the $\mathrm{TiO}_{2}-\mathrm{NP}$ dispersion stability and the effect on nauplii.

Due to the presence of the three inlets of communication with the Adriatic Sea on one side and tributary freshwater flows on the other (Zuliani et al. 2005), gradients of the physicochemical characteristics of water are established in the lagoon, from the coast to the mainland interface. Both contaminants (e.g. $\mathrm{TiO}_{2}-\mathrm{NPs}$ ) and biota in the lagoon water are thus subject to a wide range of salinities, organic matter concentration and chemical composition. 


\section{Materials and Methods}

\subsection{Sampling Area}

Natural water and zooplankton were sampled in the spring of 2013. The sampling sites (Fig. 1) were selected along a gradient of salinity and DOM, extending from saltwater close to the Malamocco inlet (Santa Maria del Mare, Site 1) to freshwater at the Dese River (Site 5). The latter belongs to the middle estuary of the river, where the typical process of the fresh and saltwater mixing occurs (Ghermandi et al. 1993). Sites 2 (near Murano Island) and 3 (at the South of Burano Island) are located in the open lagoon, where water has mainly marine characteristics. Site 4 (near Torcello Island) belongs to the lower estuary of the Dese River, where freshwater flows still influence the upper part of the water column.

At each study site, physicochemical parameters, such as salinity, temperature, dissolved oxygen, $\mathrm{pH}$, chlorophyll $a$ concentrations, conductivity and turbidity, of ambient waters

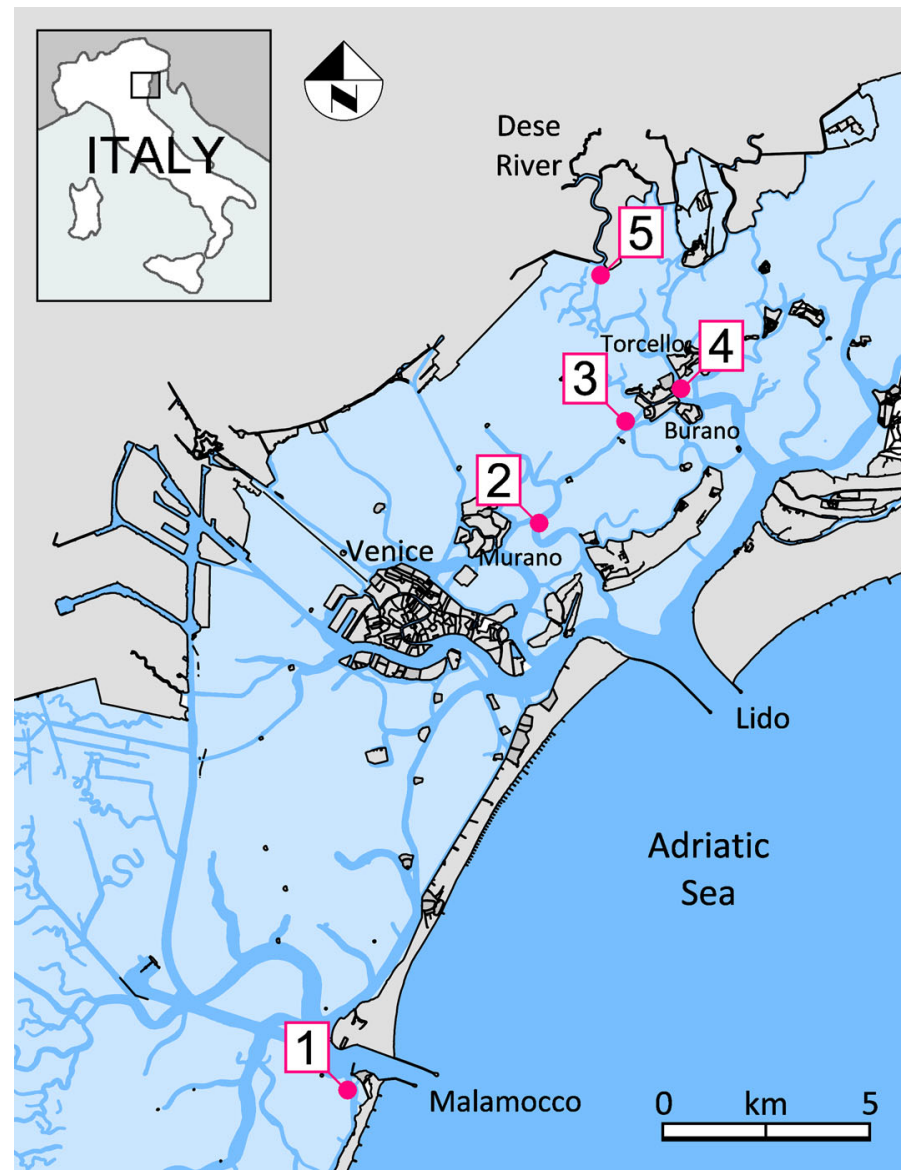

Fig. 1 Locations of the sampling sites along the salinity and DOC gradients. The exact GPS coordinates, physicochemical parameters and major cation and anion composition are provided in Table 1 
were measured in situ using a multiparametric probe (CTD Idronaut profiler, Ocean seven, Mod.316, Brugherio, Italy) at neap tide. Water transparency was also assessed using a Secchi disc. Additionally, three times $50 \mathrm{~mL}$ of waters was filtered through $0.7-\mu \mathrm{m} \mathrm{GF} / \mathrm{F}$ filters, acidified with $2 \mathrm{~N} \mathrm{HCl}$ and stored at $4{ }^{\circ} \mathrm{C}$ in the dark in amber glass vials, burned beforehand at $500{ }^{\circ} \mathrm{C}$ to measure dissolved organic carbon (DOC) concentration with a total organic carbon analyser Shimadzu TOC500A (Shimadzu Scientific Instruments, Kyoto, Japan). Waters were also sampled for cation and anion concentration analyses by ion chromatography (IC; Dionex ICS-3000, Thermo Fisher Scientific Inc., Waltham, MA) which was performed after their filtration through $0.45-\mu \mathrm{m}$ pore size filters and storage in 10 - $\mathrm{mL} \mathrm{HNO}_{3}$-cleaned PP tubes at $-20{ }^{\circ} \mathrm{C}$. Accuracy of the IC measurements was verified by the analysis of Ontario-99 certified reference material (National Water Research Institute, Environment Canada). Finally, $1 \mathrm{~L}$ of water samples was collected at each site in $\mathrm{HNO}_{3}$-cleaned PP bottles and filtered through $0.45-\mu \mathrm{m}$ pore size filters to examine $\mathrm{TiO}_{2}$ NP behaviour back in the laboratory. Plankton was sampled at the different sites by dragging a $20-\mu \mathrm{m}$ mesh net over the surface water during $5 \mathrm{~min}$ and further passed through a $45-\mu \mathrm{m}$ mesh net to collect the organisms with sizes over $45 \mu \mathrm{m}$ for the exposure to $\mathrm{TiO}_{2}$ NPs.

\section{2 $\mathrm{TiO}_{2}$-Nanoparticles and Their Characterization in Lagoon Water Samples}

Spherical shape $\mathrm{TiO}_{2}-\mathrm{NPs}$ containing $80 \%$ anatase and $20 \%$ rutile (Degussa P25, Evonik Industries, Essen, Germany) were used. According to the manufacturer, the primary size of $\mathrm{TiO}_{2}$-NPs was $50 \mathrm{~nm}$ and the approximate specific surface area was $35 \mathrm{~m}^{2} \mathrm{~g}^{-1}$. A stock dispersion of $1 \mathrm{~g} \mathrm{~L}^{-1}$ of $\mathrm{TiO}_{2}$-NPs was prepared in MilliQ water with resistivity of $18 \mathrm{M} \Omega \mathrm{cm}$ (Millipore, Zoug, Switzerland). Before each use, the dispersion was sonicated in an ultrasonication bath (Branson 5510 MTH, Emerson Industrial Automation, Fergusson, MI) for $5 \mathrm{~min}$. The appropriate amounts of the stock dispersion were added to the ambient water samples to obtain final concentrations of 10 and $100 \mathrm{mg} \mathrm{L}^{-1} \mathrm{TiO}_{2}-\mathrm{NPs}_{\text {. }}$ Although much higher than those expected in ambient water, these concentrations (Gottschalk et al. 2013) were chosen as corresponding to lowest one inducing $50 \%$ effect to the most sensitive organism in a multispecies test battery (Kahru and Ivask 2013).

Hydrodynamic diameter and electrophoretic mobility (EPM) of $\mathrm{TiO}_{2}-\mathrm{NPs}$ in ambient waters from different locations were measured after $1 \mathrm{~min}, 2$ and $24 \mathrm{~h}$ by a Malvern Zetasizer Nano-ZS (Malvern Instruments, Worcestershire, UK) at $20{ }^{\circ} \mathrm{C}$, using disposable polystyrene cuvettes (Malvern). The EPM measurement technology in Zetasizer Nano Series is based on a combination of laser Doppler velocimetry and phase analysis of light scattering that allows the measurement of high conductivity samples (e.g. lagoon water) and samples with low particle mobility. EPM was converted to $\zeta$-potential, corresponding to the potential at the hydrodynamic slipping plane in the electrostatic double layer of the $\mathrm{TiO}_{2}$-NPs, through the Smoluchovski's theory. Both z-average hydrodynamic diameter, corresponding to the intensity-weighted mean hydrodynamic diameter of the whole particle distribution, and the distributions were registered. Results are the means of three sample measurements, nine run for each, performed with freshly prepared samples on separate days.

\subsection{Effect of $\mathrm{TiO}_{2}$-NPs on Natural Plankton}

The plankton with size larger than $45 \mu \mathrm{m}$, isolated from different sampling sites, was exposed to 10 or $100 \mathrm{mg} \mathrm{L}^{-1}$ of $\mathrm{TiO}_{2}$-NPs for 2 and $24 \mathrm{~h}$ in dark at $20{ }^{\circ} \mathrm{C}$, respectively. 

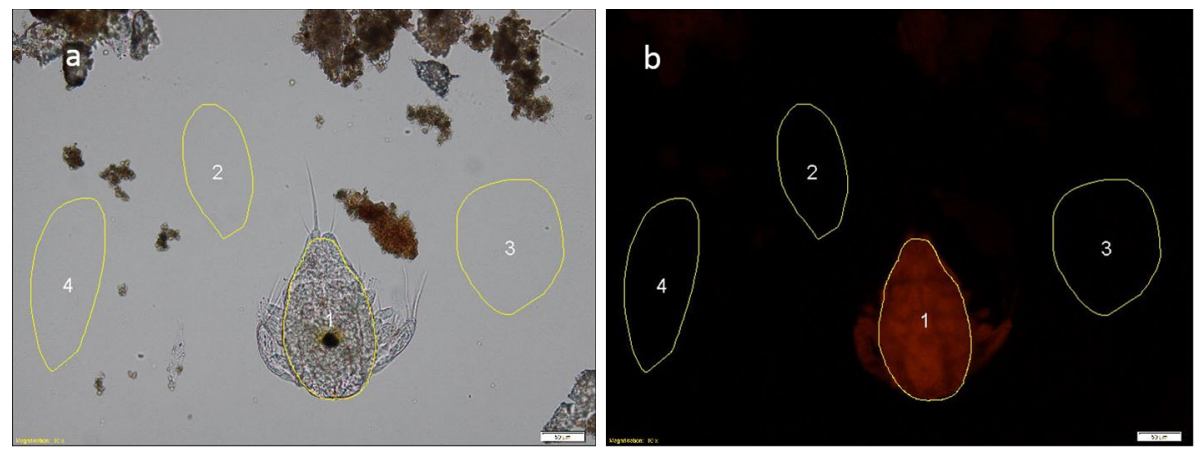

Fig. 2 Bright field image (a) and TRITC channel fluorescence image (b) of nauplii exposed to $100 \mathrm{mgL}^{-1}$ $\mathrm{TiO}_{2}$-NPs for $2 \mathrm{~h}$ in water from Site 5. Scale bar: $50 \mu \mathrm{m}$

The effect on nauplii, commonly found in the sampling locations and identified as zooplankton larvae at early development stage, was evaluated by measuring the modifications in the membrane integrity by using propidium iodide stain (PI, Invitrogen, Life Technologies, Carlsbad, CA). To this end, $12 \mu \mathrm{L}$ of $700 \mu \mathrm{M}$ PI solution was added to the plankton exposed to $\mathrm{TiO}_{2}$-NPs for 2 or $24 \mathrm{~h}$ in ambient water and kept for $15 \mathrm{~min}$ in dark. Then, the samples were washed with corresponding ambient water to eliminate residual dye and centrifuged twice at $1,000 \times g$ for $10 \mathrm{~min}$ at $4{ }^{\circ} \mathrm{C}$. The samples were fixed with $10 \mu \mathrm{L}$ of $37 \%$ formaldehyde (Sigma-Aldrich, Buchs, Switzerland) for $15 \mathrm{~min}$ and mounted on the preparation glass for microscopy observation. For each location, samples treated with PI, but not exposed to $\mathrm{TiO}_{2}$-NPs, were used as negative controls.

Plankton sampled at a given site was then observed in bright field and fluorescence modes with fluorescence microscopy (Olympus BX61, OLYMPUS, Volketswil, Switzerland). The TRITC channel was used to observe PI fluorescence. All data were treated using the Cellsens software (OLYMPUS Volketswil, Switzerland). To enable comparison between the sampling sites, nauplii were chosen for evaluation of the effects of $\mathrm{TiO}_{2}-\mathrm{NPs}$ because they were observed in all samples. The changes in the PI fluorescence in nauplii in the presence and absence of $\mathrm{TiO}_{2}$-NPs were evaluated by ImageJ (open source software, http://imagej.nih.gov/ij/). Bright field images were used to select the measurement area corresponding to the organism and the background (Fig. 2a). Then, the preselected areas were transposed onto the fluorescence image (Fig. 2b). The ratios between the PI fluorescence of the organism and the background fluorescence $\left(\mathrm{F}_{\mathrm{EXP}}=\mathrm{F}_{\mathrm{org}} / \mathrm{F}_{\mathrm{bg}}\right)$ were calculated and compared under different exposure conditions. The ratio $\mathrm{F}_{\mathrm{CTR}}=\mathrm{F}_{\mathrm{org}} / \mathrm{F}_{\mathrm{bg}}$ for the nauplii which was not exposed to $\mathrm{TiO}_{2}-\mathrm{NPs}$ was used as a negative control. All data were further normalized to the negative controls and the ratio $\mathrm{F}_{\mathrm{EXP}} / \mathrm{F}_{\mathrm{CTR}}$ present.

\subsection{Data Treatment}

Statistical differences within z-average hydrodynamic size and $\zeta$-potential of $\mathrm{TiO}_{2}-\mathrm{NPs}_{\text {as }}$ well as the ratio $\mathrm{F}_{\mathrm{EXP}} / \mathrm{F}_{\mathrm{CTR}}$ for nauplii from different sampling sites were evaluated using Student-Neuman-Keuls test for multiple comparison and one way ANOVA in Sigma Plot 11 (Systat Software Inc., San Jose, CA). 


\section{Results and Discussion}

\subsection{Physicochemical Characteristics of Ambient Water Samples}

The basic physicochemical characteristics and composition of the ambient water samples are presented in Table 1. The $\mathrm{pH}$ varied in a relatively narrow range between 8.2 and 7.9. Site 1, in the central lagoon, near the Malamocco inlets is characterized by the highest salinity, and cation and anion composition, typical for marine water. The Sites 2-5 were located in the northern part of the lagoon and were chosen along the salinity and DOC gradients (Fig. 1; Table 1). Indeed, the salinity decreased gradually from 32.20 in Site 1 to $0.41 \mathrm{~g} \mathrm{~L}^{-1}$ in Site 5. Site 5, Dese River, is also characterized by the highest turbidity and the highest chlorophyll $a$ concentrations. The major cation and anion composition varied in a wide range among the sites; however, $\mathrm{Na}^{+}, \mathrm{K}^{+}, \mathrm{Ca}^{2+}$ and $\mathrm{Mg}^{2+}$ concentrations followed the same tendency as the salinity. The ratio between monovalent $\left[\mathrm{Na}^{+}+\mathrm{K}^{+}\right]$and divalent cations $\left[\mathrm{Ca}^{2+}+\mathrm{Mg}^{2+}\right]$ changed from about seven in Site 1, representative of sea water, to about 2.9 in Site 5, Dese River, representative of freshwater. High concentrations of $\mathrm{Cl}^{-}$, $\mathrm{NO}_{3}{ }^{-}$and $\mathrm{SO}_{4}{ }^{2-}$ were measured in water collected in Site 3, which may be due to an occasional discharge of domestic sewage. By contrast, the DOC concentration, used as a measure of DOM content in ambient water, increased from $4.2 \mathrm{mg} \mathrm{L}^{-1}$ in Site 1 to $17.4 \mathrm{mg} \mathrm{L}^{-1}$ in Site 5. The above characteristics could have important implications for the counterions in the double layer around $\mathrm{TiO}_{2}$-NPs (Stumm and Morgan 1981) and the adsorption of DOM to $\mathrm{TiO}_{2}$-NPs and thus their reactivity and effects on biota in transitional lagoon environment. Indeed, counterions neutralize particle surface charge, which is reflected by the less negative values of $\zeta$-potential and enhanced particle-particle aggregation, while co-ions can impact surface charges by preferential adsorption (Stumm and Morgan 1981). It could be hypothesized that the decrease in salinity and increase in DOM concentrations (from Site 1 to Site 5) will favour the stability of $\mathrm{TiO}_{2}-\mathrm{NPs}$ in water column and thus their ability to interact with and affect the planktonic organisms.

\section{2 $\mathrm{TiO}_{2}$-NPs Dispersion Stability in the Ambient Water Over Time}

The stability of $\mathrm{TiO}_{2}-\mathrm{NP}$ agglomerates in the salinity and DOC gradients in the ambient water of Venetian Lagoon was characterized by the $\mathrm{z}$-average hydrodynamic diameter and size distributions as well as $\zeta$-potential used as a surrogate for particle surface charge at $1 \mathrm{~min}, 2$ and $24 \mathrm{~h}$.

An increase in the z-averaged hydrodynamic size with the exposure time and a formation of micrometre agglomerates was observed for both 100 and $10 \mathrm{mg} \mathrm{L}^{-1} \mathrm{TiO}_{2}-\mathrm{NPs}$ in all ambient waters with variable salinity and DOC content (Fig. 3a, c). The aggregation seemed to be a very fast process given the large agglomerates already formed in a minute after the addition of the $\mathrm{TiO}_{2}$-NPs to the ambient water with increasing salinity as indicated by the z-average diameters measured. For a given time, however, the size of the formed agglomerates was strongly dependent on the nominal $\mathrm{TiO}_{2}-\mathrm{NPs}$ concentrations, with about twice larger agglomerates in the dispersions of $100 \mathrm{mg} \mathrm{L}^{-1} \mathrm{TiO}_{2}-\mathrm{NPs}$, which is expected, due to the increased probability of collisions between the particles (Stumm and Morgan 1981).

$\zeta$-potential had negative, but above $-20 \mathrm{mV}$, values revealing the instability of the dispersions (Fig. 3b, d). The strong decrease in the absolute value of the negative $\zeta$ potential with respect to the values provided by the manufacturer points to a large modification of the surface charge of the agglomerates, which is mainly due to the mono- and 


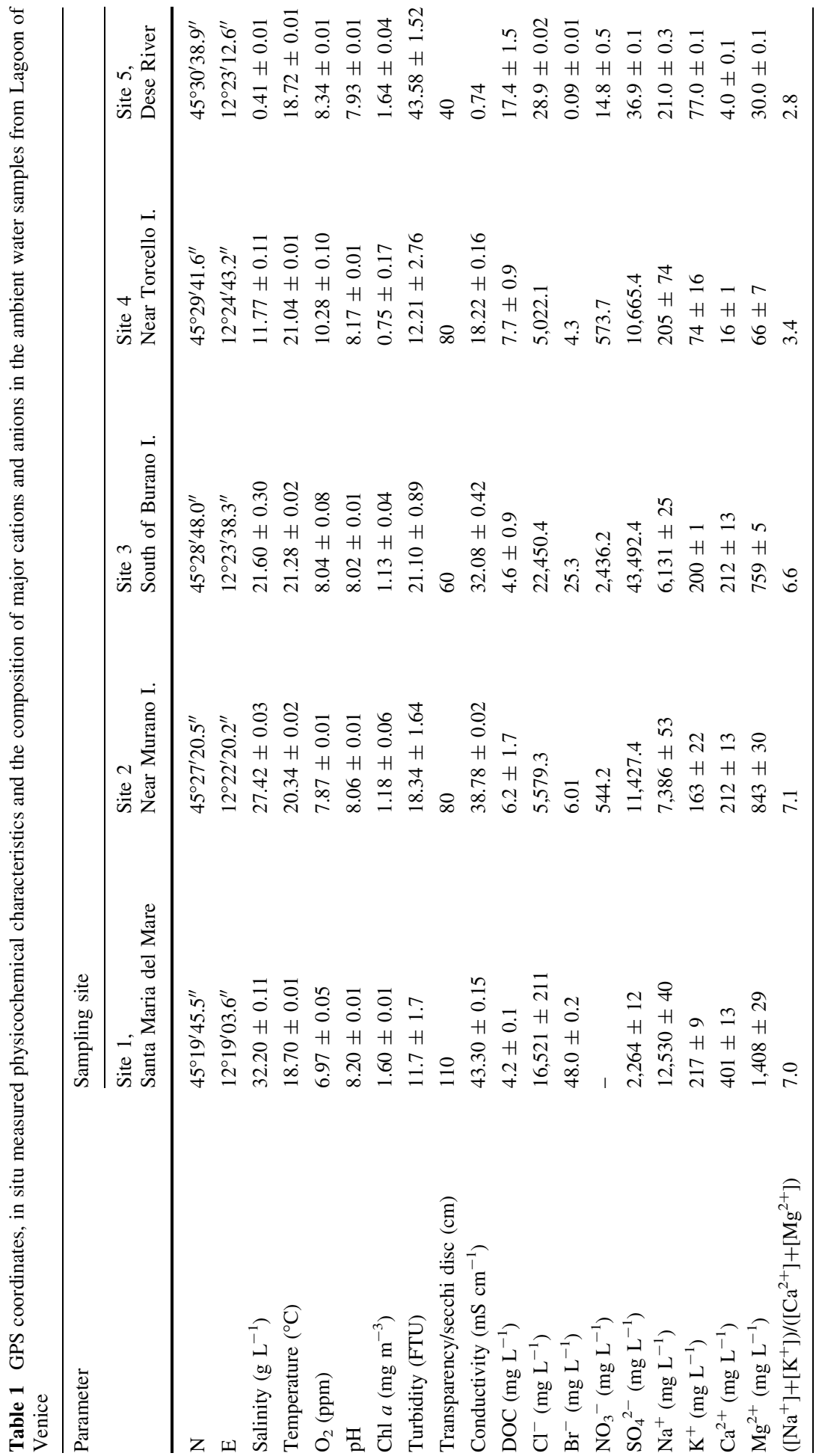



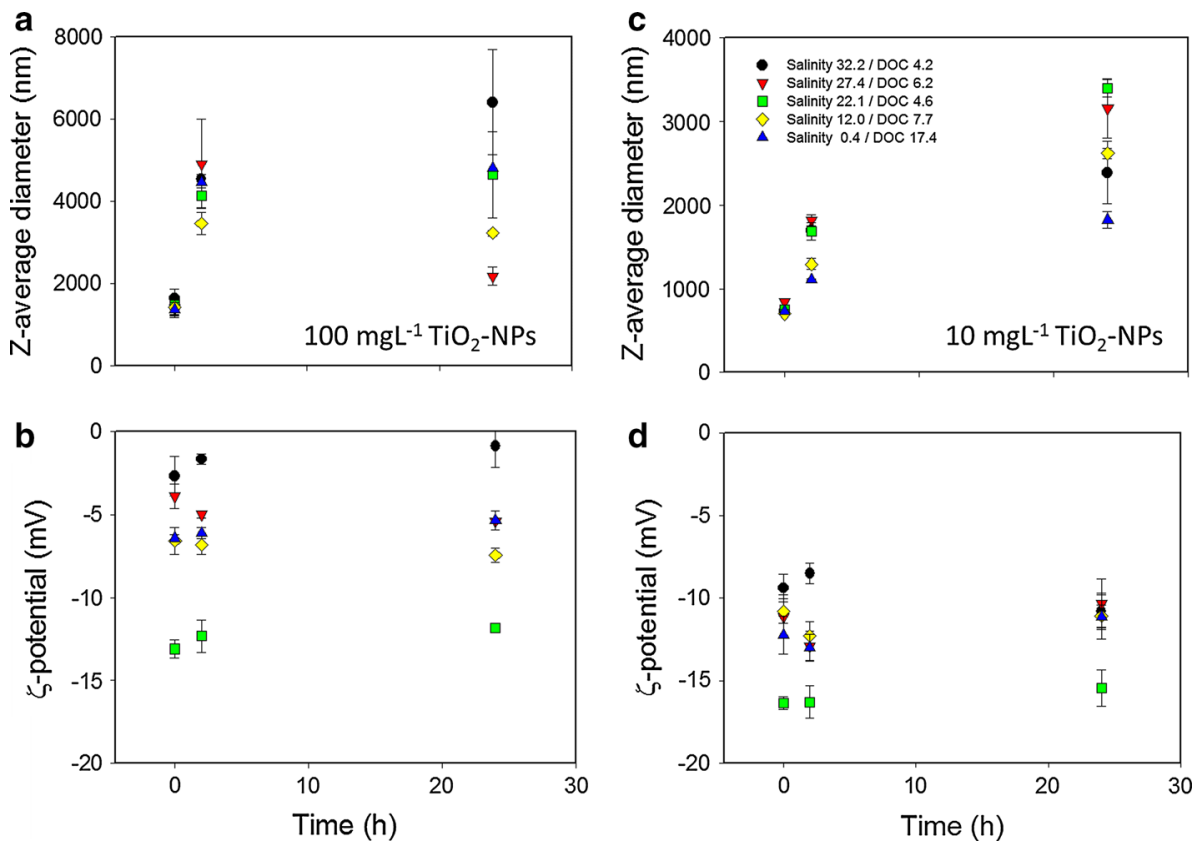

Fig. 3 Temporal changes of the z-average hydrodynamic size and $\zeta$-potential of $\mathrm{TiO}_{2}-\mathrm{NPs}_{\text {in }}$ ambient water from different sampling sites along the salinity and DOC gradients. Nominal concentrations: (a, b) 100 $\mathrm{mgL}^{-1} \mathrm{TiO}_{2}$-NPs, (c, d) $10 \mathrm{mgL}^{-1} \mathrm{TiO}_{2}$-NPs. Values of $\mathrm{z}$-average hydrodynamic diameter larger than $6,000 \mathrm{~nm}$ are out of the measurement range

divalent cation adsorption. The temporal changes found for $\zeta$-potential were much less pronounced compared to those observed for $\mathrm{z}$-average hydrodynamic size. The $\zeta$-potential values in water sampled in Site 1, representative of marine water, were close to 0 in agreement with the observed larger sizes agglomerates. Nonetheless, no surface charge inversion was observed due to the concomitant adsorption of negatively charged organic matter and major anions present in the ambient waters. In each ambient water sample, $\zeta$ potentials measured in the dispersions containing $10 \mathrm{mg} \mathrm{L}^{-1} \mathrm{TiO}_{2}-\mathrm{NPs}$ were more negative than those of the samples containing $100 \mathrm{mg} \mathrm{L}^{-1} \mathrm{TiO}_{2}-\mathrm{NPs}$, suggesting higher stability of the dispersion containing lower $\mathrm{TiO}_{2}-\mathrm{NP}$ concentrations. The latter is also in agreement with the lower z-average hydrodynamic sizes determined in the dispersions of $10 \mathrm{mg} \mathrm{L}{ }^{-1} \mathrm{TiO}_{2}$-NPs. The above observations are in line with the assumption that the adsorption of negatively charged organic matter per particle is greater at $10 \mathrm{mg} \mathrm{L}^{-1}$ than at $100 \mathrm{mg} \mathrm{L}^{-1}$ of $\mathrm{TiO}_{2}$-NPs. In addition, the hydrodynamic diameter and $\zeta$-potential measurements of $100 \mathrm{mg} \mathrm{L}^{-1} \mathrm{TiO}_{2}$-NPs in ambient water from Site 1 with the highest salinity and lowest DOC content exhibited larger uncertainty at $24 \mathrm{~h}$ than the samples in the waters from other sampling sites.

$\mathrm{Bi}$ - and even three-modal distributions of the hydrodynamic size were observed in the ambient water dispersions of $\mathrm{TiO}_{2}-\mathrm{NPs}$ (Figs. 4, 5). For $10 \mathrm{mg} \mathrm{L}{ }^{-1} \mathrm{TiO}_{2}-\mathrm{NP}$ dispersions, a shift of the lower size peak towards larger sizes at $2 \mathrm{~h}$ was observed for all ambient water. By contrast, after $24 \mathrm{~h}$, no peak corresponding to larger size fraction was found under most of the studied conditions (Fig. 4). This trend could be possibly explained by the formation of very large agglomerates that are out of the measurement range and/or settle down by sedimentation. Indeed, concurrent sedimentation of larger agglomerates with consequent 

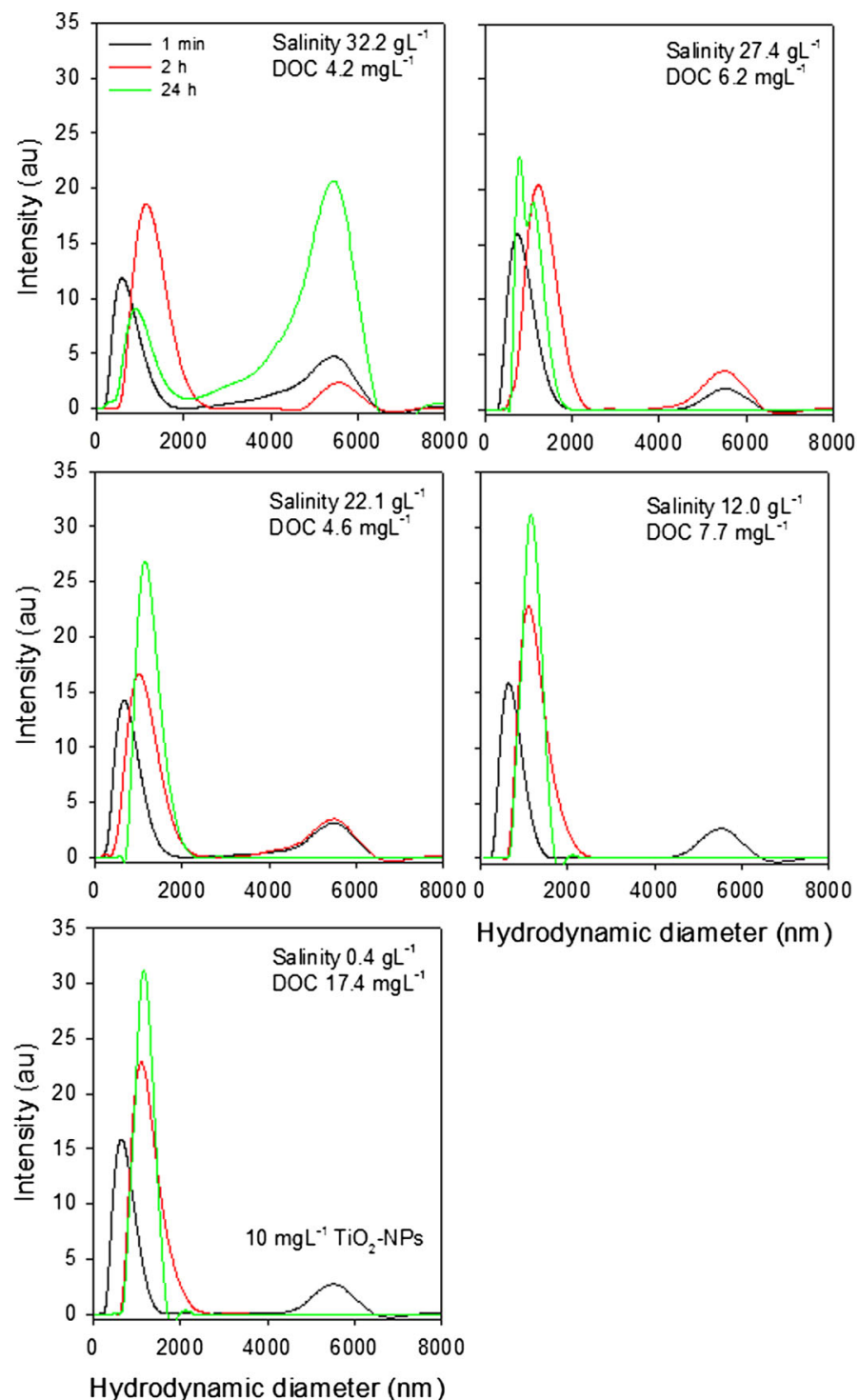

Hydrodynamic diameter $(\mathrm{nm})$

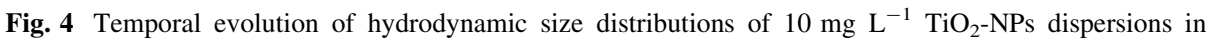
lagoon water along the salinity and DOC gradients

decrease in the average hydrodynamic size of NPs has been shown to occur both in artificial and natural sea water (Brunelli et al. 2013; Keller et al. 2010). The above observations also reveal the tendency of a decrease in the dispersed $\mathrm{TiO}_{2}-\mathrm{NP}$ agglomerates that could interact with planktonic organisms.

The size distribution data measured in the dispersions containing $100 \mathrm{mg} \mathrm{L}^{-1} \mathrm{TiO}_{2}-\mathrm{NPs}$ appeared even more difficult to interpret (Fig. 5) - three-modal distributions were observed $24 \mathrm{~h}$ after addition of NPs to the ambient water with salinity below $12 \mathrm{~g} \mathrm{~L}^{-1}$. The results revealed wide size distributions and large polydispersity, indicating a dynamic character of the $\mathrm{TiO}_{2}-\mathrm{NPs}$ behaviour in transient lagoon water as well as very fast formation of the agglomerates 

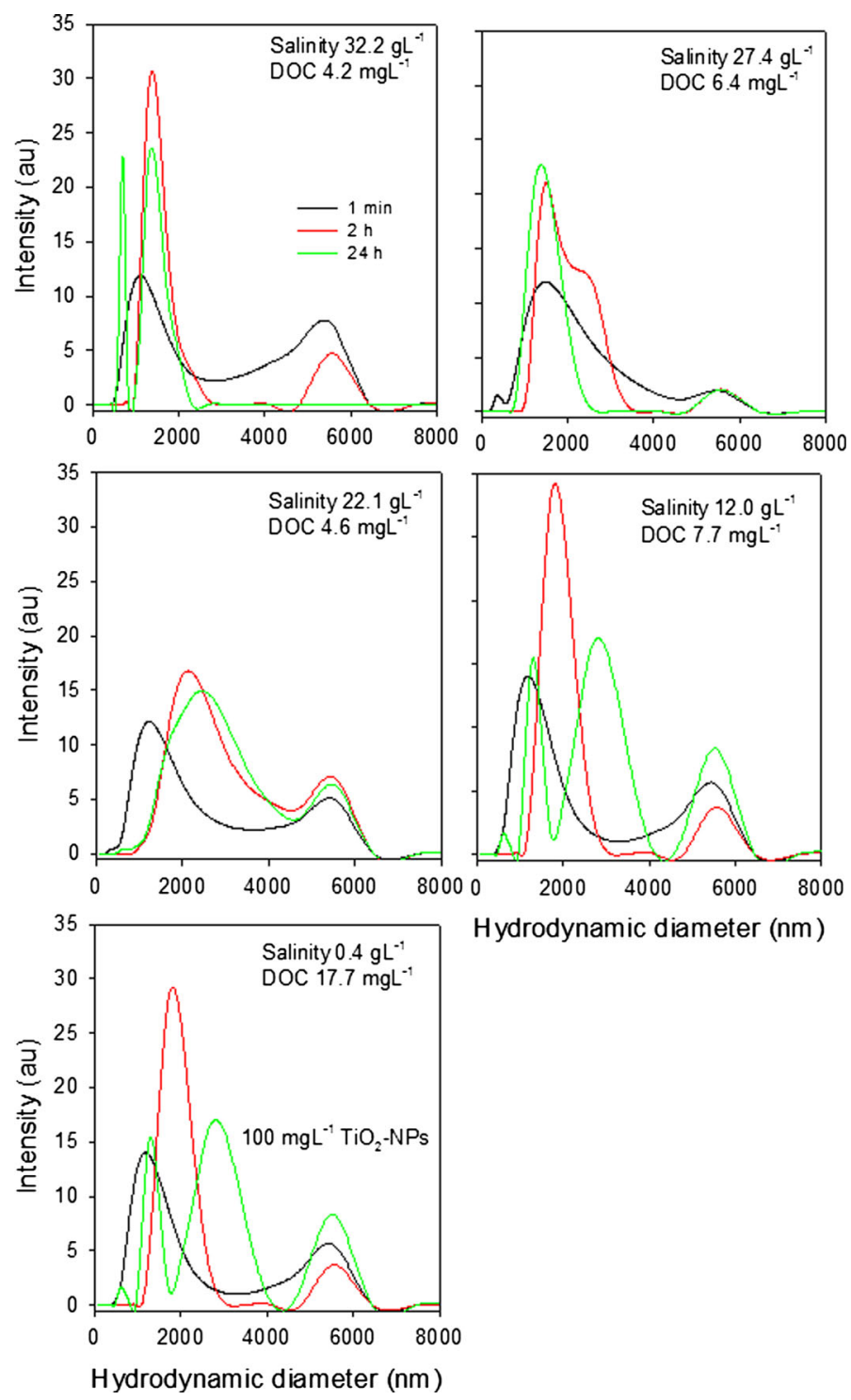

Hydrodynamic diameter $(\mathrm{nm})$

Fig. 5 Temporal evolution of hydrodynamic size distributions of $100 \mathrm{mgL}^{-1} \mathrm{TiO}_{2}$-NPs dispersions in lagoon water along the salinity and DOC gradients

in NP concentration-dependent manner. This is in general agreement with the existing literature about $\mathrm{TiO}_{2}-\mathrm{NP}$ aggregation kinetics in ambient water (Brunelli et al. 2013; French et al. 2009; Keller et al. 2010; Ottofuelling et al. 2011; von der Kammer et al. 2010). For example, a very rapid formation of the agglomerates with size from 300 to $>500 \mathrm{~nm}$ within the first 2 min was shown to occur in sea water (Keller et al. 2010). Formation of agglomerates of $\mathrm{TiO}_{2}-\mathrm{NPs}_{\text {sith }}$ the average size of 492 and $598 \mathrm{~nm}$, regardless of the initial concentrations, was reported at $0.2 \mathrm{~h}$ in the water of Venetian Lagoon and Adriatic Sea, with a general increase in the agglomerate size up to $800-880 \mathrm{~nm}$ by $25 \mathrm{~h}$ (Brunelli et al. 2013). Formation of micrometre-sized agglomerates 
within 15 min was also shown for $\mathrm{TiO}_{2}$-NPs in artificial solutions at ionic strength from $4.5 \times 10^{-3}$ to $1.65 \times 10^{-2} \mathrm{M}$ (French et al. 2009).

\section{3 $\mathrm{TiO}_{2}$-NP Suspension Stability Over Salinity and Dissolved Organic Carbon Gradients}

To gain further insight on how the ambient water gradients influence the stability of the $\mathrm{TiO}_{2}$-NP dispersions, the z-average hydrodynamic sizes and $\zeta$-potential were analysed as a function of the salinity, the ratio between mono- and bivalent cations and the DOC concentrations in water from the different sampling sites (Figs. 6, 7). Although the absolute
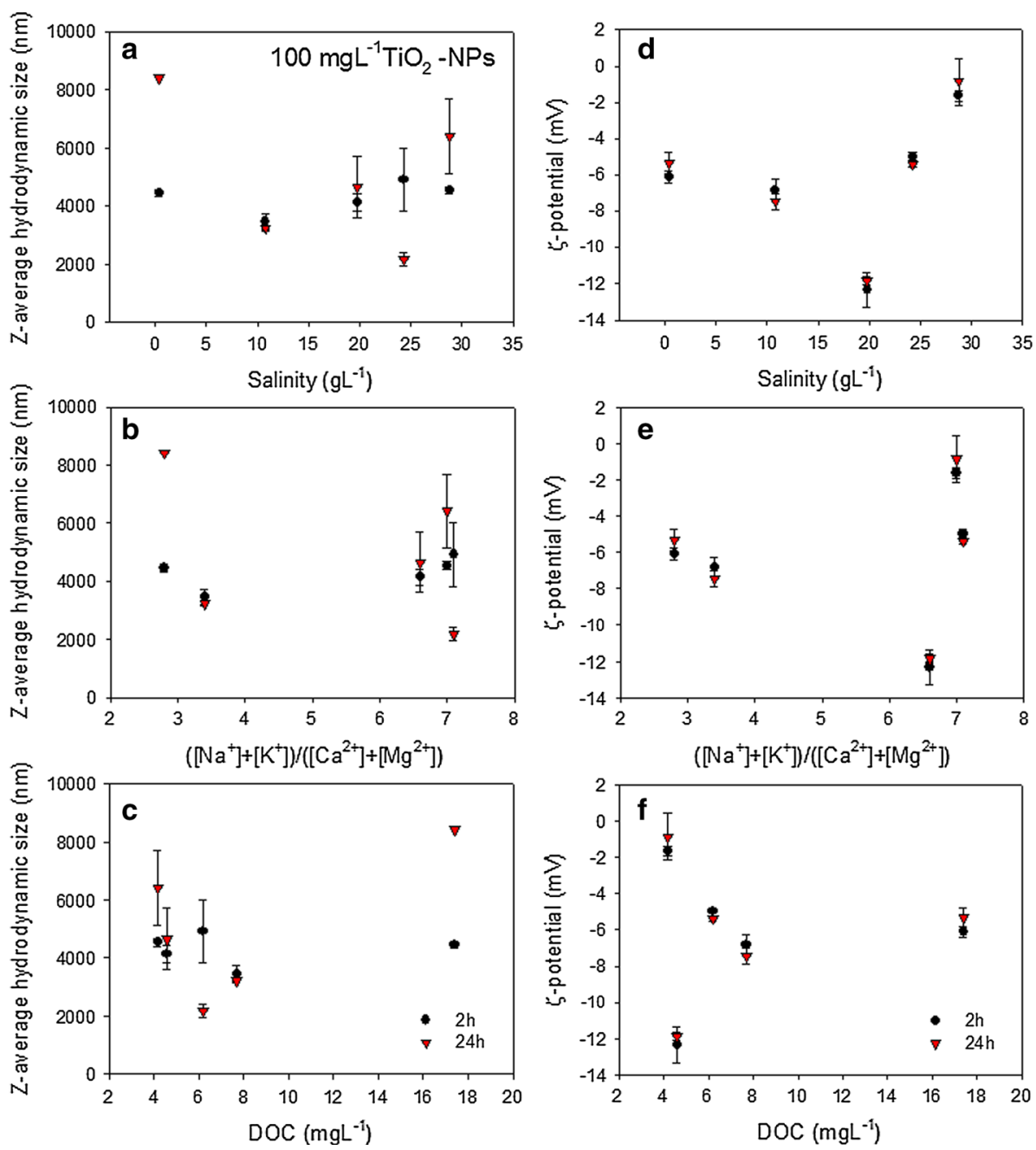

Fig. 6 Dependence of the z-average hydrodynamic size and $\zeta$-potential on the ambient water salinity (a,d), ratio between mono-and bivalent cations $(\mathbf{b}, \mathbf{e})$ and dissolved organic carbon $(\mathbf{c}, \mathbf{f})$. $\mathrm{TiO}_{2}-\mathrm{NP}$ nominal concentration was $100 \mathrm{mgL}^{-1}$ 

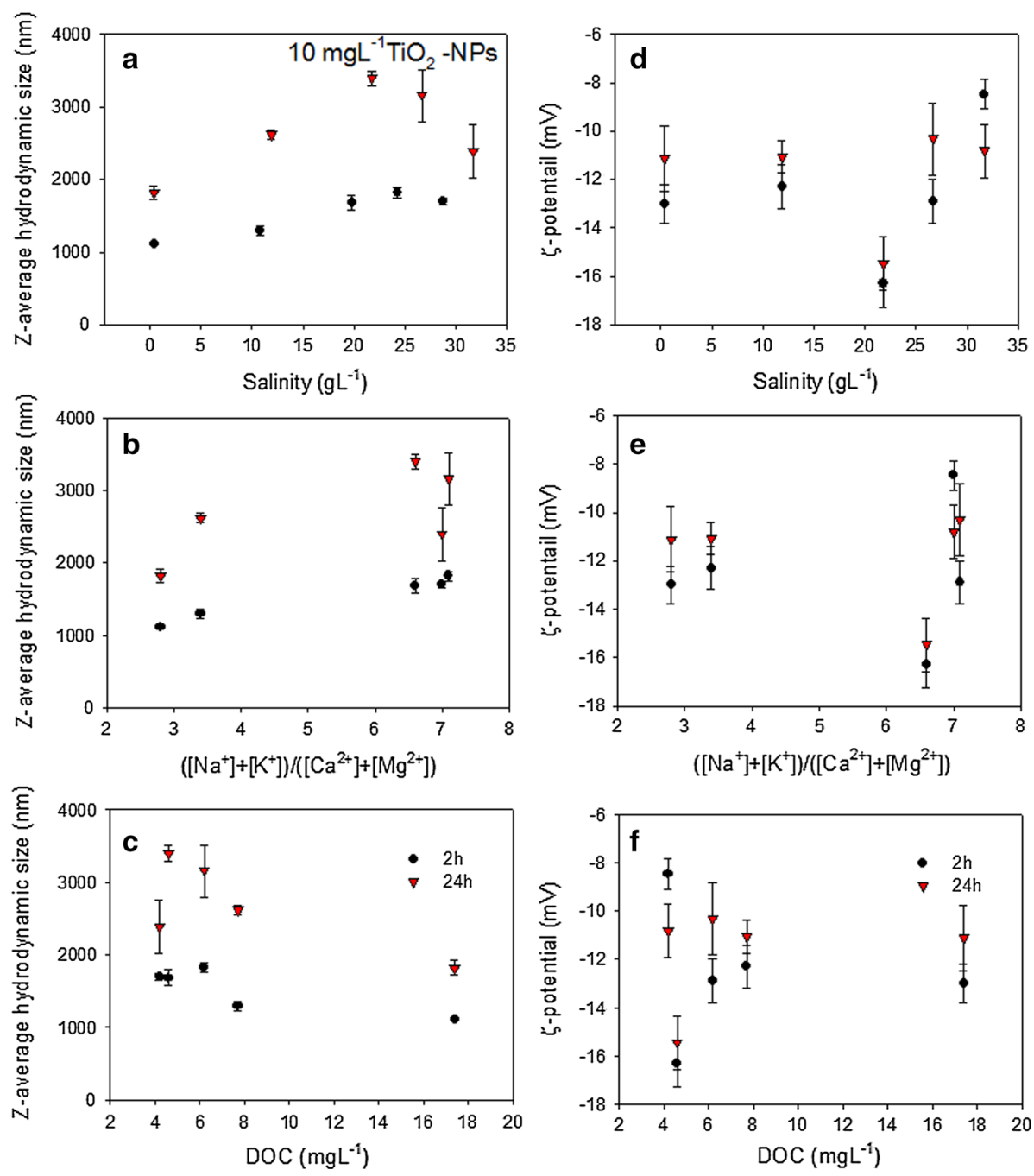

Fig. 7 Dependence of the z-average hydrodynamic size and $\zeta$-potential on the ambient water salinity (a, d), ratio between mono-and bivalent cations $(\mathbf{b}, \mathbf{e})$ and dissolved organic carbon $(\mathbf{c}, \mathbf{f})$. $\mathrm{TiO}_{2}-\mathrm{NP}$ nominal concentration was $10 \mathrm{mgL}^{-1}$

values were different, the z-average hydrodynamic diameter of 10 and $100 \mathrm{mg} \mathrm{L}^{-1} \mathrm{TiO}_{2^{-}}$ NPs increased with the salinity and ratio of $\left(\left[\mathrm{Na}^{+}\right]+\left[\mathrm{K}^{+}\right]\right) /\left(\left[\mathrm{Ca}^{2+}\right]+\left[\mathrm{Mg}^{2+}\right]\right)$ after both 2- and 24-h incubation, as could be expected by the increasing probability of interactions of $\mathrm{TiO}_{2}$-NPs with the surrounding medium. Similar increase in the agglomerate size of $\mathrm{TiO}_{2}$-NPs with the salinity and cation concentration has been shown previously both in artificial freshwater and sea water (Brunelli et al. 2013). The values of $\zeta$-potential of $\mathrm{TiO}_{2}$-NPs were negative in the studied waters, however, much less negative than $-20 \mathrm{mV}$ demonstrating instability of the dispersions and the pronounced tendency of the dispersions to agglomerate and settle. $\zeta$-potential values were less negative and closer to zero at higher salinity with more pronounced trend in the dispersions of $10 \mathrm{mg} \mathrm{L}^{-1}$ of $\mathrm{TiO}_{2}-\mathrm{NPs}$ 
(Figs. 6d, 7d). These findings are in agreement with published results showing that $\zeta$ potential was significantly influenced by the increasing salinity of reconstructed sea water (Wang et al. 2014).

Increasing DOC concentrations in ambient waters had the opposite effect and resulted in a decrease in the z-average hydrodynamic diameter, in parallel to more negative values of $\zeta$-potential (Fig. 6c, f), suggesting increased stability of the $\mathrm{TiO}_{2}-\mathrm{NP}$ dispersions. Indeed, higher DOC concentration could enhance the amount of the adsorbed organic matter on the agglomerates and thus increase their negative charge. These tendencies were, however, less prevalent in case of $100 \mathrm{mg} \mathrm{L}{ }^{-1} \mathrm{TiO}_{2}$-NPs (Fig. 7c, f). Such a $\mathrm{TiO}_{2}-\mathrm{NP}$ concentrationdependent difference in the aggregation behaviour is probably related to the difference in a $\mathrm{DOC} / \mathrm{TiO}_{2}$ concentration ratio which is less favourable for the increase in the negative surface charge in the highly concentrated dispersions of $\mathrm{TiO}_{2}$-NPs. Much lower agglomerate sizes and more negative $\zeta$-potentials of $\mathrm{TiO}_{2}$-NPs, which did not follow the above discussed trends, were measured in water sampled near Site 3, which is characterized with very high concentrations of $\mathrm{NO}_{3}{ }^{-}$and $\mathrm{SO}_{4}^{2}$ (Table 1). Indeed, anions, such as $\mathrm{SO}_{4}{ }^{2-}$ and $\mathrm{Cl}^{-}$, have been shown to affect the surface charge of $\mathrm{TiO}_{2}-\mathrm{NPs}$ with $\zeta$-potential reported to be more negative at higher $\mathrm{SO}_{4}{ }^{2-} / \mathrm{Cl}^{-}$ratios (Mukherjee and Weaver 2010).

Taken together, the above results clearly show the variation of the $\mathrm{TiO}_{2}$ - $\mathrm{NP}$ stability over the salinity and DOC gradients as well as highlight the importance of the ionic composition of the ambient water, in particular high $\mathrm{NO}_{3}{ }^{-}$and $\mathrm{SO}_{4}{ }^{2-}$ concentrations, as well as the initial $\mathrm{TiO}_{2}-\mathrm{NP}$ concentration. However, it was not possible to distinguish the effect of a single water variable due to the complex and dynamic nature and co-variation of these parameters in the ambient water. Nonetheless, the results are consistent with the findings of the agglomeration studies performed in model systems, artificial and real sea water (Brunelli et al. 2013; Keller et al. 2010; Lowry et al. 2012). For example, the agglomeration behaviour in northern Adriatic Sea water and Venetian Lagoon water with salinity of 32 and DOC of $1.2 \mathrm{mg} \mathrm{L}^{-1}$ was shown to be primarily affected by the initial concentration of $\mathrm{TiO}_{2}$-NPs and then the duration of the experiment (Brunelli et al. 2013). Slightly negative but close to zero values of the electrophoretic mobilities of $10 \mathrm{mg} \mathrm{L}^{-1}$ metal oxide NPs were reported in ambient water from Santa Barbara (CA), Bodega Head (CA) and UCSB campus lagoon (CA) as compared to freshwater (Keller et al. 2010). Our results are also consistent with the findings of numerous model systems demonstrating that: (1) the increase in the ionic strength favoured the aggregation in NP dispersions (Domingos et al. 2010; French et al. 2009; von der Kammer et al. 2010); (2) the model organic matter, Suwannee River fulvic acid (SRFA), stabilized the dispersions under conditions favouring SRFA adsorption, i.e. due to increased steric repulsion (Domingos et al. 2009; Palomino et al. 2013; von der Kammer et al. 2010); (3) the DOM adsorption and stabilization effect were dependent on its concentrations (Ottofuelling et al. 2011; von der Kammer et al. 2010), its origin (Erhayem and Sohn 2014) and composition, e.g. SRFA vs alginate (Loosli et al. 2014), co-presence of DOM and mono- and divalent ions (Ottofuelling et al. 2011; von der Kammer et al. 2010); (4) the divalent cations, such as $\mathrm{Ca}^{2+}$, could increased the aggregation despite the presence of DOM (Domingos et al. 2010; Ottofuelling et al. 2011); (5) the presence of synthetic surfactants stabilized NPs similarly to DOM (Topuz et al. 2014).

The enhancement of the aggregation of the NPs over salinity gradients and formation of micrometre-sized agglomerates could be expected to have important implication for their effect on the lagoon plankton. It has been reported that the formation of micrometre-sized agglomerates and their settling will decrease the agglomerate concentrations in contact with plankton and their bioavailability and effects (von Moos et al. 2014). Increased 
agglomerate size could also result in decrease in their surface area and thus their reactivity (Klaine et al. 2008) and could decrease their toxicity, which is induced by the surfacemediated reactions such as reactive oxygen species generation (Lowry et al. 2012; von Moos and Slaveykova 2014).

\subsection{Effect of $\mathrm{TiO}_{2}$-NPs on Nauplii Isolated from Different Sampling Sites}

The effect of the $\mathrm{TiO}_{2}$-NP agglomerates on nauplii sampled at different sites along the salinity and DOC gradients was probed by PI staining (Figs. 8, 9). The PI fluorescence of

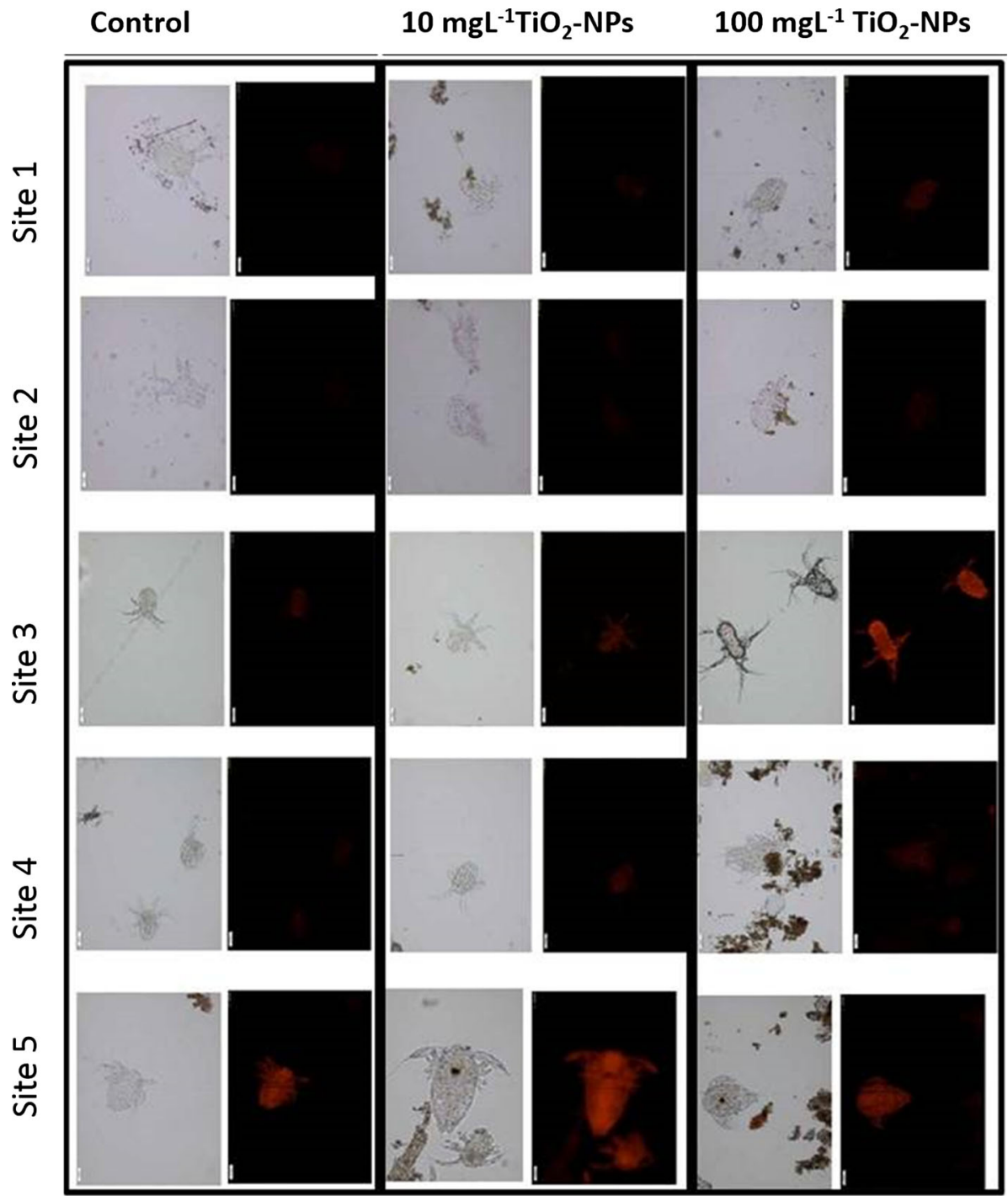

Fig. 8 Examples of bright field and fluorescence images of nauplii exposed to $10 \mathrm{mg} \mathrm{L}^{-1}$ and $100 \mathrm{mgL}^{-1}$ of $\mathrm{TiO}_{2}$-NPs for $2 \mathrm{~h}$ and unexposed controls at different sampling locations. Red propidium iodide fluorescence corresponds to stained nauplii. Scale bar of $50 \mu \mathrm{m}$ 

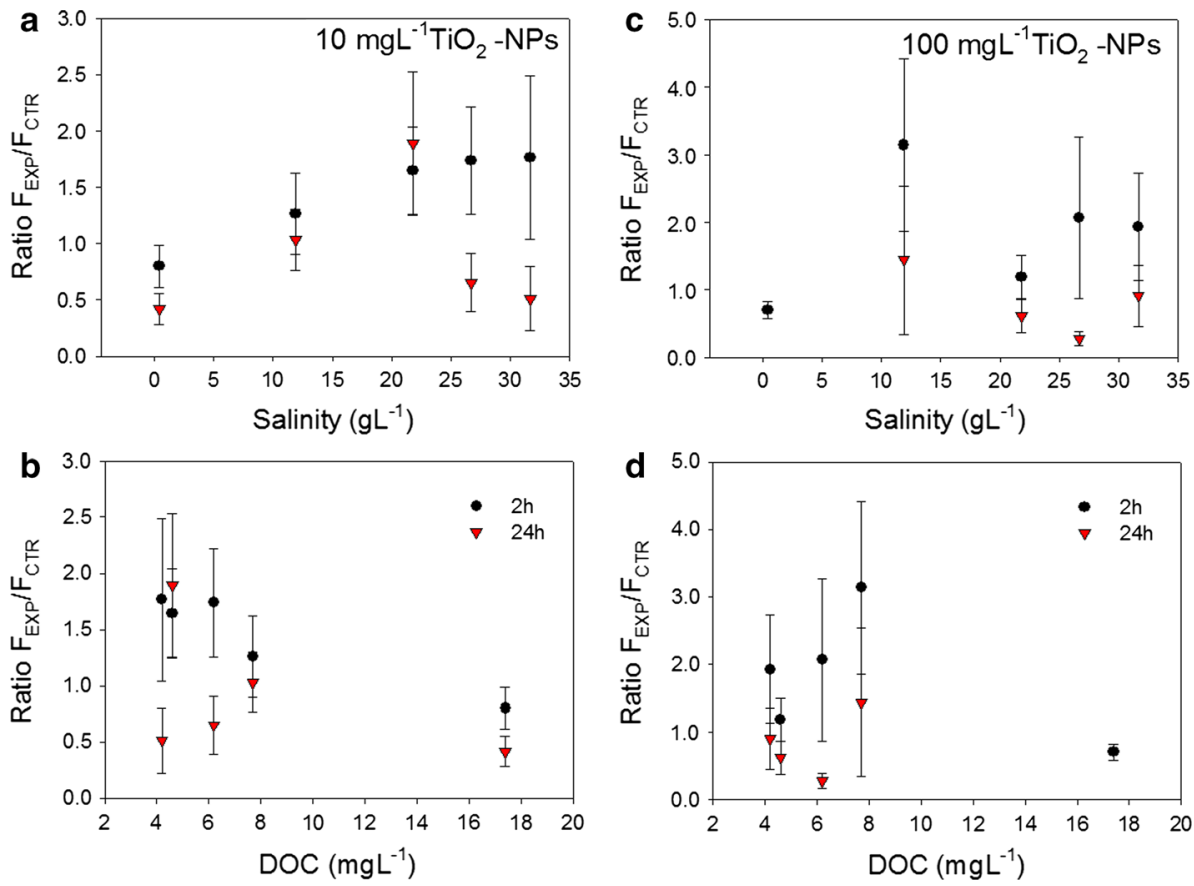

Fig. 9 Dependence of the increase in the $\mathrm{F}_{\mathrm{EXP}}$ of nauplii normalized to the negative controls $\mathrm{F}_{\mathrm{CTR}}$ in the absence of $\mathrm{TiO}_{2}$-NPs on the salinity and DOC gradients after 2- and 24-h exposure. $\mathrm{TiO}_{2}-\mathrm{NP}$ nominal concentrations were $10 \mathrm{mg} \mathrm{L}^{-1}(\mathbf{a}, \mathbf{b})$ and $100 \mathrm{mg} \mathrm{L}^{-1}$ (c, d)

nauplii exposed to $\mathrm{TiO}_{2}$-NP agglomerates $\left(\mathrm{F}_{\mathrm{EXP}}\right)$ for $2 \mathrm{~h}$ increased as compared to those non-treated with $\mathrm{TiO}_{2}-\mathrm{NPs}\left(\mathrm{F}_{\mathrm{CTR}}\right)$. This increase was more pronounced for the nauplii exposed to $100 \mathrm{mg} \mathrm{L}^{-1}$ of $\mathrm{TiO}_{2}-\mathrm{NPs}$ at $2 \mathrm{~h}$. However, at 24-h exposure, the ratios $\mathrm{F}_{\mathrm{EXP}} /$ $\mathrm{F}_{\mathrm{CTR}}$ were close to one, illustrating comparable PI staining for unexposed nauplii and those exposed to both $\mathrm{TiO}_{2}$-NPs concentrations. The lack of or little effect at 24-h exposure could result, on the one hand, from the increase in the agglomerate size and thus decrease in their reactivity and, on the other hand, from the decrease in the agglomerate concentrations in the water column. The possible depuration of the $\mathrm{TiO}_{2}-\mathrm{NP}$ agglomerates by nauplii after 24-h exposure would probably play a secondary role after $24 \mathrm{~h}$ in comparison with 2-h exposure, because nauplii were shown to excrete only 3-12\% of $\mathrm{TiO}_{2}$ content in comparable conditions (Ates et al. 2013). The increase in PI fluorescence is usually interpreted as a sign of membrane permeability alteration, since PI is membrane impermeant stain and excluded from cells with intact membranes (Arndt-Jovin and Jovin 1989). However, the interpretation of nauplii staining with PI have to be made with caution. The increased red PI fluorescence associated with nauplii could be also a result of the nonspecific binding of PI to the components of their cuticle rather than penetration through the membrane. Indeed, it was shown that PI could stain cell walls (Rounds et al. 2011) without penetrating the membrane.

Interestingly, a clear correlation was observed between the increases in the $\mathrm{F}_{\mathrm{EXP}} / \mathrm{F}_{\mathrm{CTR}}$ ration for nauplii exposed to $10 \mathrm{mg} \mathrm{L}^{-1} \mathrm{TiO}_{2}$-NPs after 2-h exposure and increasing salinity, and decrease in the $\mathrm{F}_{\mathrm{EXP}} / \mathrm{F}_{\mathrm{CTR}}$ at increasing DOC concentrations, revealing the protective role of DOM in the interactions with microorganisms. No clear trends and 


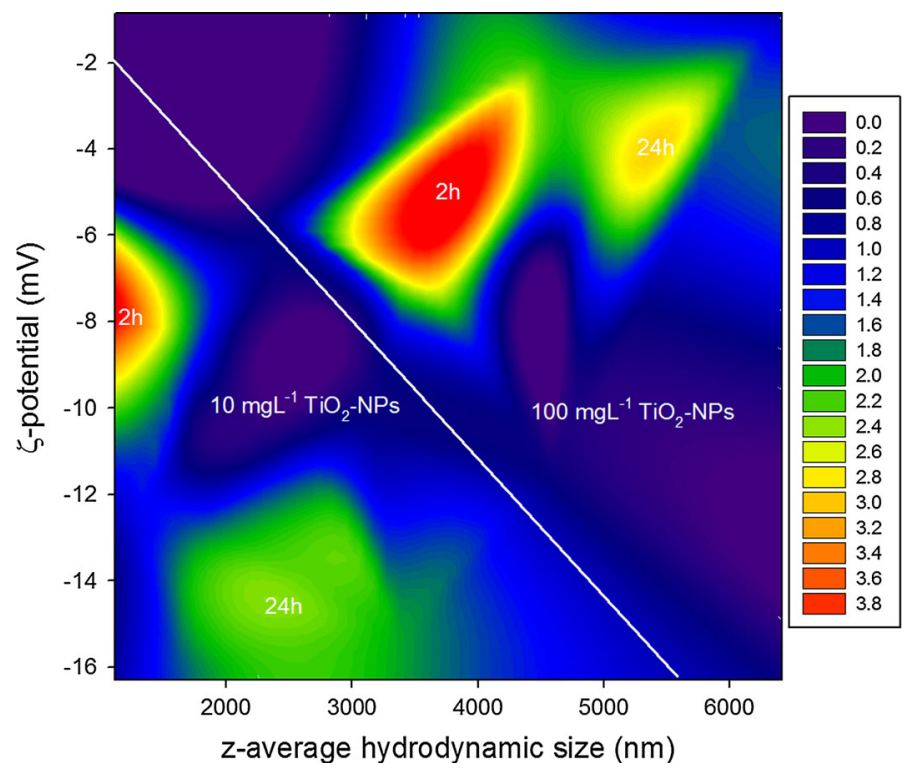

Fig. 10 Contour plot illustrating the relationships between the changes $\mathrm{F}_{\mathrm{EXP}} / \mathrm{F}_{\mathrm{CTR}}$ of nauplii versus $\zeta$ potential and agglomerate size. The colour coding and the respective values in the legend designate the values of $\mathrm{F}_{\mathrm{EXP}} / \mathrm{F}_{\mathrm{CTR}}$ ratio

linkage between the ratio $\mathrm{F}_{\mathrm{EXP}} / \mathrm{F}_{\mathrm{CTR}}$ and the salinity and DOC gradients were seen neither in 24-h exposure to $10 \mathrm{mg} \mathrm{L}^{-1} \mathrm{TiO}_{2}$-NPs nor in 2- and 24-h exposure to $100 \mathrm{mg} \mathrm{L}^{-1}$ $\mathrm{TiO}_{2}$-NPs. It is also worth noting that the exposure experiments in the present study are performed with nauplii originating from sampling locations with different physicochemical and habitat characteristics that are heterogeneous in nature and differs in development stage, cuticle and membrane permeability (Horst and Freeman 1993).

\subsection{Linking the $\mathrm{TiO}_{2}$-NP Agglomerate Characteristics with Effect on Nauplii}

To explore the relationship between the $\mathrm{TiO}_{2}-\mathrm{NP}$ agglomerate "reactivity" and the effect on nauplii, the determined $\mathrm{F}_{\mathrm{EXP}} / \mathrm{F}_{\mathrm{CTR}}$ were analysed as a function of the agglomerate size and $\zeta$-potential (Fig. 10). Four well distinguished zones in the contour plot can be seen, corresponding to dispersions containing 10 and $100 \mathrm{mg} \mathrm{L}^{-1} \mathrm{TiO}_{2}-\mathrm{NPs}_{\text {s }}$ and 2- and 24-h exposure, showing the prime importance of the dispersion concentrations and exposure duration. For a given exposure concentration, the $\mathrm{F}_{\mathrm{EXP}} / \mathrm{F}_{\mathrm{CTR}}$ was bigger in the dispersions containing $\mathrm{TiO}_{2}$-NPs with lower size agglomerates, i.e. at 2-h exposure.

\section{Conclusions}

The present work studied the behaviour of $\mathrm{TiO}_{2}-\mathrm{NP}$ agglomerates in a highly dynamic transitional environment, such as Venetian Lagoon, and potential effect to nauplii sampled form different locations along the salinity and DOC gradients. Under all studied conditions, a fast formation of micrometre-sized agglomerates was observed, with a highest size observed in the sampling sites with lower DOC and higher salinity. The agglomerates were 
characterized by wide size distributions and large polydispersity. A positive correlation between the formation of the larger agglomerates with less negative $\zeta$-potential and increase in the salinity and concomitant decrease in the DOC concentrations was found. However, above observations were also dependent on the $\mathrm{TiO}_{2}-\mathrm{NPs}$ concentrations and exposure duration. The exposure to micrometre-size agglomerates of $\mathrm{TiO}_{2}-\mathrm{NPs}$ resulted to an increase in the fluorescence of PI stained nauplii at 2-h exposure, but had no significant effect at $24 \mathrm{~h}$. The effect was more pronounced in dispersions containing $100 \mathrm{mg} \mathrm{L}^{-1}$ $\mathrm{TiO}_{2}$-NPs. An increase in fluorescence of PI stained nauplii with respect to the non-stained controls was found at increased salinity and decreased DOC in 2-h exposure, while no trend was observed at 24-h exposure. Taken together, the above results show that in addition to concentration and exposure duration both size and $\zeta$-potential have to be taken into account when determining the effects of $\mathrm{TiO}_{2}-\mathrm{NP}$ agglomerates on nauplii.

Acknowledgments The present work was supported in part by the NRP 64 Swiss National Science Foundation, project 406440-131280. CP is grateful for the A. Lombard scholarship from the Société de Physique et d'Histoire Naturelle de Genève. We thank Fréderic Loosli for his help with the ion chromatography analyses.

Conflict of interest All authors state that there are no conflicts of interest.

\section{References}

Arndt-Jovin DJ, Jovin TM (1989) Fluorescence labeling and microscopy of DNA. Methods Cell Biol 30:417-448

Ates M, Daniels J, Arslan Z, Farah IO (2013) Effects of aqueous suspensions of titanium dioxide nanoparticles on Artemia salina: assessment of nanoparticle aggregation, accumulation, and toxicity. Environ Monit Assess 185:3339-3348. doi:10.1007/s10661-012-2794-7

Auffan M, Rose J, Bottero JY, Lowry GV, Jolivet JP, Wiesner MR (2009) Towards a definition of inorganic nanoparticles from an environmental, health and safety perspective. Nat Nanotechnol 4:634-641. doi:10.1038/nnano.2009.242

Baker TJ, Tyler CR, Galloway TS (2014) Impacts of metal and metal oxide nanoparticles on marine organisms. Environ Pollut 186:257-271. doi:10.1016/j.envpol.2013.11.014

Barmo C, Ciacci C, Canonico B, Fabbri R, Cortese K, Balbi T, Marcomini A, Pojana G, Gallo G, Canesi L (2013) In vivo effects of $\mathrm{n}-\mathrm{TiO}_{2}$ on digestive gland and immune function of the marine bivalve Mytilus galloprovincialis. Aquat Toxicol 132-133:9-18. doi:10.1016/j.aquatox.2013.01.014

Brunelli A, Pojana G, Callegaro S, Marcomini A (2013) Agglomeration and sedimentation of titanium dioxide nanoparticles $\left(\mathrm{n}-\mathrm{TiO}_{2}\right)$ in synthetic and real waters. J Nanoparticle Res 15. doi:10.1007/ s11051-013-1684-4

Chen X, Mao SS (2007) Titanium dioxide nanomaterials: synthesis, properties, modifications, and applications. Chem Rev 107:2891-2959. doi:10.1021/cr0500535

Cherchi C, Gu AZ (2010) Impact of titanium dioxide nanomaterials on nitrogen fixation rate and intracellular nitrogen storage in Anabaena variabilis. Environ Sci Technol 44:8302-8307. doi:10.1021/ es $101658 \mathrm{p}$

Chowdhury I, Walker SL, Mylon SE (2013) Aggregate morphology of nano- $\mathrm{TiO}_{2}$ : role of primary particle size, solution chemistry, and organic matter. Environ Sci: Process Impacts 15:275-282. doi:10.1039/ C2EM30680H

D'Agata A, Fasulo S, Dallas LJ, Fisher AS, Maisano M, Readman JW, Jha AN (2014) Enhanced toxicity of 'bulk' titanium dioxide compared to 'fresh' and 'aged' nano- $\mathrm{TiO}_{2}$ in marine mussels (Mytilus galloprovincialis). Nanotoxicology 8:549-558. doi:10.3109/17435390.2013.807446

Domingos RF, Tufenkji N, Wilkinson KJ (2009) Aggregation of titanium dioxide nanoparticles: role of a fulvic acid. Environ Sci Technol 43:1282-1286. doi:10.1021/es8023594

Domingos RF, Peyrot C, Wilkinson KJ (2010) Aggregation of titanium dioxide nanoparticles: role of calcium and phosphate. Environ Chem 7:61-66. doi:10.1071/en09110

Erhayem M, Sohn M (2014) Effect of humic acid source on humic acid adsorption onto titanium dioxide nanoparticles. Sci Total Environ 470:92-98. doi:10.1016/j.scitotenv.2013.09.063 
Fairbairn EA, Keller AA, Mädler L, Zhou D, Pokhrel S, Cherr GN (2011) Metal oxide nanomaterials in seawater: linking physicochemical characteristics with biological response in sea urchin development. J Hazard Mater 192:1565-1571. doi:10.1016/j.jhazmat.2011.06.080

French RA, Jacobson AR, Kim B, Isley SL, Penn RL, Baveye PC (2009) Influence of ionic strength, pH, and cation valence on aggregation kinetics of titanium dioxide nanoparticles. Environ Sci Technol 43:1354-1359. doi:10.1021/es802628n

Ghermandi G, Campoleti D, Cecchi R, Costa F, Zaggia L, Zonta R (1993) Trace metal behaviour during fresh and salt water mixing in the Venice Lagoon. Nucl Instrum Methods Phys Res B 75:330-333

Gottschalk F, Sun T, Nowack B (2013) Environmental concentrations of engineered nanomaterials: review of modeling and analytical studies. Environ Pollut 181:287-300. doi:10.1016/j.envpol.2013.06.003

Handy RD, von der Kammer F, Lead JR, Hassellov M, Owen R, Crane M (2008) The ecotoxicology and chemistry of manufactured nanoparticles. Ecotoxicology 17:287-314. doi:10.1007/s10646-008-0199-8

Horst MN, Freeman JA (1993) The crustacean integument morphology and biochemistry. CRC-Press, Boca Raton

Ju-Nam Y, Lead JR (2008) Manufactured nanoparticles: an overview of their chemistry, interactions and potential environmental implications. Sci Total Environ 400:396-414. doi:10.1016/j.scitotenv.2008.06. 042

Kahru A, Ivask A (2013) Mapping the dawn of nanoecotoxicological research. Acc Chem Res 46:823-833. doi:10.1021/ar3000212

Kashiwada S (2006) Distribution of nanoparticles in the see-through medaka (Oryzias latipes). Environ Health Perspect 114:1697-1702. doi:10.1289/ehp.9209

Keller AA, Wang H, Zhou D, Lenihan HS, Cherr G, Cardinale BJ, Miller R, Ji Z (2010) Stability and aggregation of metal oxide nanoparticles in natural aqueous matrices. Environ Sci Technol 44:1962-1967. doi:10.1021/es902987d

Klaine SJ, Alvarez PJJ, Batley GE, Fernandes TF, Handy RD, Lyon DY, Mahendra S, McLaughlin MJ, Lead JR (2008) Nanomaterials in the environment: behavior, fate, bioavailability, and effects. Environ Toxicol Chem 27:1825-1851. doi:10.1897/08-090.1

Loosli F, Le Coustumer P, Stoll S (2014) Effect of natural organic matter on the disagglomeration of manufactured $\mathrm{TiO}_{2}$ nanoparticles. Environ Sci: Nano 1:154-160. doi:10.1039/C3EN00061C

Lowry GV, Gregory KB, Apte SC, Lead JR (2012) Transformations of nanomaterials in the environment. Environ Sci Technol 46:6893-6899. doi:10.1021/es300839e

Matranga V, Corsi I (2012) Toxic effects of engineered nanoparticles in the marine environment: model organisms and molecular approaches. Mar Environ Res 76:32-40. doi:10.1016/j.marenvres.2012.01. 006

Miller RJ, Lenihan HS, Muller EB, Tseng N, Hanna SK, Keller AA (2010) Impacts of metal oxide nanoparticles on marine phytoplankton. Environ Sci Technol 44:7329-7334. doi:10.1021/es100247x

Mukherjee B, Weaver JW (2010) Aggregation and charge behavior of metallic and nonmetallic nanoparticles in the presence of competing similarly-charged inorganic ions. Environ Sci Technol 44:3332-3338. doi:10.1021/es903456e

Ottofuelling S, Von Der Kammer F, Hofmann T (2011) Commercial titanium dioxide nanoparticles in both natural and synthetic water: comprehensive multidimensional testing and prediction of aggregation behavior. Environ Sci Technol 45:10045-10052. doi:10.1021/es2023225

Palomino D, Yamunake C, Coustumer PL, Stoll S (2013) Stability of $\mathrm{TiO}_{2}$ nanoparticles in presence of fulvic acids Importance of pH. J Colloid Sci Biotechnol 2:62-69. doi:10.1166/jcsb.2013.1033

Park S, Woodhall J, Ma G, Veinot JG, Cresser MS, Boxall AB (2014) Regulatory ecotoxicity testing of engineered nanoparticles: are the results relevant to the natural environment? Nanotoxicology 8:583-592. doi:10.3109/17435390.2013.818173

Petosa AR, Jaisi DP, Quevedo IR, Elimelech M, Tufenkji N (2010) Aggregation and deposition of engineered nanomaterials in aquatic environments: role of physicochemical interactions. Environ Sci Technol 44:6532-6549. doi:10.1021/es100598h

Rounds CM, Lubeck E, Hepler PK, Winship LJ (2011) Propidium iodide competes with $\mathrm{Ca}^{2+}$ to label pectin in pollen tubes and arabidopsis root hairs. Plant Physiol 157:175-187. doi:10.1104/pp.111.182196

Sharma VK (2009) Aggregation and toxicity of titanium dioxide nanoparticles in aquatic environment-a review. J Environ Sci Health Part A-Tox/Hazard Subst Environ Eng 44:1485-1495. doi:10.1080/ 10934520903263231

Stumm W, Morgan JJ (1981) Aquatic chemistry. Wiley, New York

Topuz E, Sigg L, Talinli I (2014) A systematic evaluation of agglomeration of Ag and $\mathrm{TiO}_{2}$ nanoparticles under freshwater relevant conditions. Environ Pollut 193:37-44. doi:10.1016/j.envpol.2014.05.029 
von der Kammer F, Ottofuelling S, Hofmann T (2010) Assessment of the physico-chemical behavior of titanium dioxide nanoparticles in aquatic environments using multi-dimensional parameter testing. Environ Pollut 158:3472-3481. doi:10.1016/j.envpol.2010.05.007

von Moos N, Slaveykova VI (2014) Oxidative stress induced by inorganic nanoparticles in bacteria and aquatic microalgae-state of the art and knowledge gaps. Nanotoxicology 8:605-630. doi:10.3109/ 17435390.2013 .809810

von Moos N, Bowen P, Slaveykova VI (2014) Bioavailability of inorganic nanoparticles to planktonic bacteria and aquatic microalgae in freshwater. Environ Sci: Nano 1:214-232. doi:10.1039/ C3EN00054K

Wang H, Burgess RM, Cantwell MG, Portis LM, Perron MM, Wu F, Ho KT (2014) Stability and aggregation of silver and titanium dioxide nanoparticles in seawater: role of salinity and dissolved organic carbon. Environ Toxicol Chem 33:1023-1029. doi:10.1002/etc.2529

Zhu X, Zhou J, Cai Z (2011) The toxicity and oxidative stress of $\mathrm{TiO}_{2}$ nanoparticles in marine abalone (Haliotis diversicolor supertexta). Mar Pollut Bull 63:334-338. doi:10.1016/j.marpolbul.2011.03.006

Zuliani A, Zaggia L, Collavini F, Zonta R (2005) Freshwater discharge from the drainage basin to the Venice Lagoon (Italy). Environ Int 31:929-938. doi:10.1016/j.envint.2005.05.004 